\title{
On the Quality of Steel from Continuously Cast Billet*
}

\author{
By Shinkichi Koike, ${ }^{* *}$ Akira Kimura, ${ }^{* *}$ Tooru Hikage, ${ }^{* *}$ and Toshio Watanabe**
}

\section{Synopsis}

A general description of the plant of the Hachinohe works, North Japan Special Steel Co., Ltd. and a review of the continuous casting operations performed there are made in this report specifically in connection with the frequency of casting operations, amount of castings, and casting loss.

In respect of the quality of products rolled or forged of some types of continuously cast billets, comparisons were made with those of products from the conventional ingot and it was found that there was no appreciable difference.

As the result of these studies, it has become possible to increase the operation rate of continuous casting of $L D$ converter melt or electric arc furnace melt to 12-15 times/day and to supply the continuously cast billets to the market.

\section{Introduction}

As the first plant of Junghans-Mannesmann-Boehler system erected in Japan, the continuous casting plant of the Hachinohe works started the casting operation in February, 1964. It has repeated about ten thousand casting cycles over a period of three years. During the period, various types of steel melted by the LD converter and the electric arc furnace were cast, and the rolled and forged products were subjected to some material tests.

This report covers a brief outline of the steel plant operation, and results of comparison of the quality of products rolled and forged of various types of continuously cast billets with those of products from the conventional ingots.

\section{Steel Plant Facilities and Operation Record ${ }^{11}$}

A schematic view of the steel plant is given in Fig. 1. The steel melted by the $10 \mathrm{t}$ LD converter or the $10 \mathrm{t}$ electric arc furnace is transported by a ladle car to a continuous casting yard. In the yard the ladle is hanged by a $30 \mathrm{t}$ crane up to a casting bed for the subsequent casting operation. Although the refining process by the LD converter or the electric arc furnace is nothing dissimilar to the one of conventional steel ingot, due consideration has to be given to the temperature drop of the melt during tapping and transportation in a ladle. The temperature drops actually determined were as follows:

\begin{tabular}{l|cc}
\hline & $\begin{array}{c}\text { During } \\
\text { tapping } \\
\left({ }^{\circ} \mathrm{C}\right)\end{array}$ & $\begin{array}{c}\text { During transpor- } \\
\text { tation in a ladle } \\
\left({ }^{\circ} \mathrm{C}\right)\end{array}$ \\
\hline LD converter steel & $80-90$ & $50-60$ \\
Electric arc furnace steel & $15-25$ & $35-45$ \\
\hline
\end{tabular}

The continuous casting apparatus is capable of casting billets in two strands $(90,115,165$, and $175 \mathrm{~mm}$ squ.) or slabs in one strand $(750 \times 150 \mathrm{~mm})$. At present, 12-15 casting cycles are performed per day. Fig. 2 shows the frequencies of casting operations by month since the outset of the plant operation, monthly productions of cast billets and slabs, and the transition of steel loss by stoppage failure.

The time required for mould replacement is about five hours. Each mould is repaired after every 100 casting operations and has an average life of about 600 castings.

\section{Qualities of Rolled and Forged Steels}

In respect of the quality of products rolled or forged of some types of continuously cast billets, comparisons

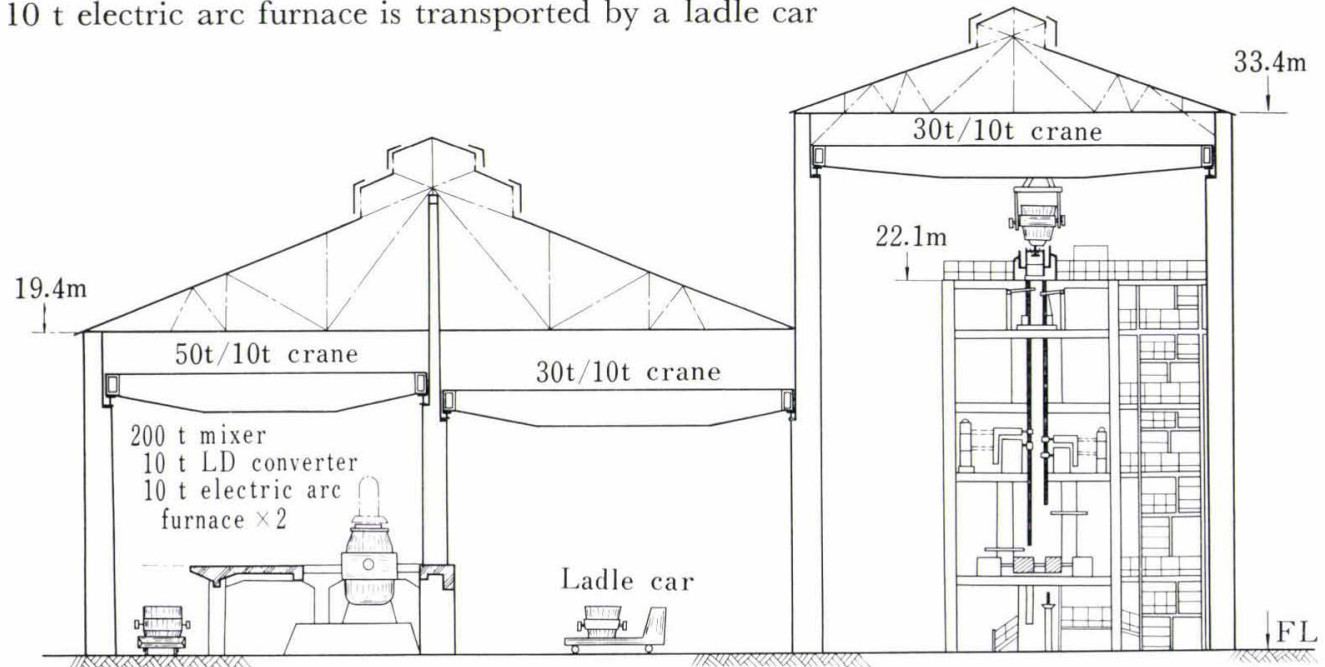

Fig. 1.

Cross section of steel plant of the Hachinohe works of North Japan Special Steel Co., Ltd.

* Presented at the 70th ISIJ Meeting, October, 1965 in Kitakyushu, the 71st, April, 1966 in Tokyo, and the 72 nd, October, 1966 in Amagasaki. Manuscript received July 9, 1967.

** The Hachinohe works, North Japan Special Steel Co., Ltd., Hachinohe. 


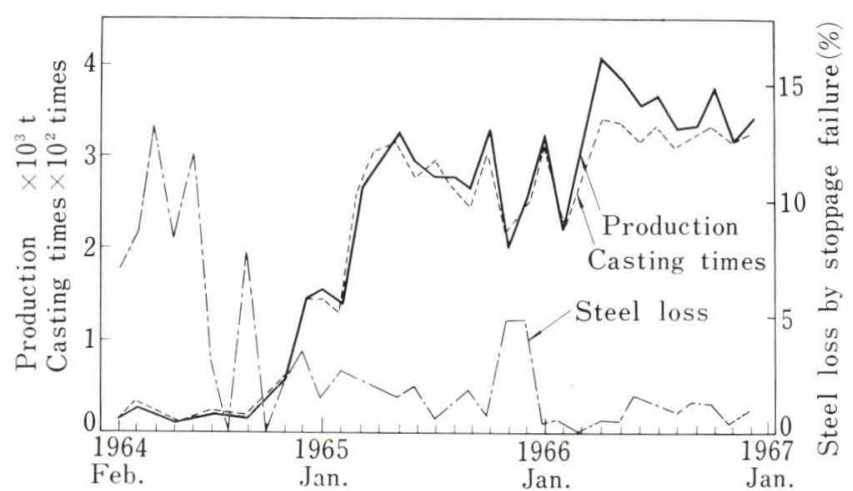

Fig. 2. Production of cast billets and slabs, and transition of steel loss by stoppage failure

were made with those of products from the conventional ingots.

At present, some of the information included here has already been published. ${ }^{2-6)}$ C. Wells, ${ }^{7)}$ D. J. Wulpi ${ }^{8)}$ D. I. Brown, ${ }^{9)}$ and R. Rosegger ${ }^{10)}$ indicated for the low- and middle-carbon steel and the low alloy steel that properties of continuously cast steels were similar to those of the conventional ingots when continuously cast steels were provided by the reduction at least 4 by hot working from the as-cast billet.

However, for the high-carbon steel and the stainless steel, discussion on the properties of such steels has been conspicuously absent from the literature. Consequently, the authors have performed experiments to make clear that their quality would be equivalent to that of the conventional ingot.

\section{Hard Steel Wire Rods and Stainless Steel Wire Rods} Hard Steel Wire Rods ${ }^{11}$

115 and $165 \mathrm{~mm}$ squ. continuously cast billets smelted by the double slagged and catch carbon process with the LD converter were rolled, cold drawn to wires, and were examined for the material qualities after rolling. The results were compared with those of products from the conventional ingot. The chemical compositions of the hard steel wire rod specimens examined were as shown in Table 1 .

The continuously cast billets were rolled to wire rods of $5.5 \mathrm{~mm}$ in diameter, without conditioning of billet surface. Photo. 1 shows a macrostructure of transversal section of a continuously cast billet and that of transversal and longitudinal sections of $5.5 \mathrm{~mm}$ dia. wire rods. While the $5.5 \mathrm{~mm}$ dia. wire rods show a dense and homogeneous structures, a thin linear central segregation is observed in part of the macrostructure of longitudinal section.

Presumably responsible for this is the central segregation in the continuously cast billet which remained unremoved in the product rolled to the form of $5.5 \mathrm{~mm}$
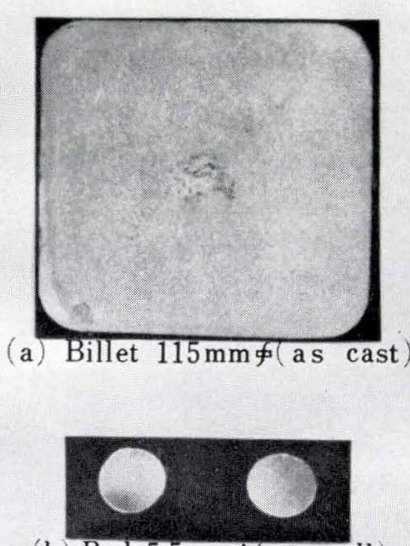

(b) $\operatorname{Rod} 5.5 \mathrm{~mm} \phi$ (as roll)
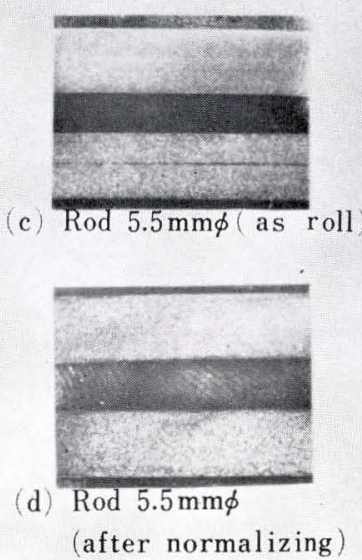

Photo. 1. Macrostructure of cast billet and $5.5 \mathrm{~mm}$ wire rod

dia. wire rods. The surface conditions of the $5.5 \mathrm{~mm}$ dia. wire rods were not distinguishable from those of the product obtained from the conventional ingots. It thus became clear that the use of continuously cast billets enables surface conditioning to be skipped.

Experimentally the $5.5 \mathrm{~mm}$ dia. wire rods were further drawn directly to a diameter of $3.0 \mathrm{~mm}$ after nine passes through dies. This $3.0 \mathrm{~mm}$ dia. wire was kept at $970^{\circ} \mathrm{C}$, quenched in lead at $570^{\circ} \mathrm{C}$, and then drawn to $0.93 \mathrm{~mm}$ in diameter. No breaking of wire occurred during the drawing operation. In each of these steps, the test specimens were obtained and then subjected to mechanical tests. Fig. 3 shows mechanical properties of the hard steel wire in different stages of cold drawing. The specimens were also tested for maximum drawability. The wire could be drawn to a diameter of $0.485 \mathrm{~mm}$, with a reduction of $97.4 \%$. Such drawability was similar to that of the product obtained from the conventional ingot. Fatigue tests were conducted with $1.20 \mathrm{~mm}$ dia. wire specimens. The results are compared with those of the products obtained from the conventional ingots. As shown in

Table 1. Chemical analyses of hard steel wire rods and stainless steel wire rods (\%)

\begin{tabular}{c|c|ccccccc}
\hline Steel quality & Specimen & $\mathrm{G}$ & $\mathrm{Si}$ & $\mathrm{Mn}$ & $\mathrm{P}$ & $\mathrm{S}$ & $\mathrm{Ni}$ & $\mathrm{Cr}$ \\
\hline \multirow{2}{*}{ Hard steel wire rods } & $A$ & 0.60 & 0.25 & 0.49 & 0.016 & 0.018 & tr. & 0.01 \\
& $B$ & 0.60 & 0.26 & 0.50 & 0.025 & 0.012 & 0.01 & 0.03 \\
\hline Stainless steel wire rods & & 0.06 & 0.51 & 0.96 & 0.039 & 0.026 & 9.21 & 18.12 \\
\hline
\end{tabular}


Fig. 4, there is no noticeable difference between the both specimens.

These results of experiments suggest no problem in practical applications of the continuously cast billets produced by the LD converter for subsequent production of the hard steel wire.

\section{Stainless Steel Wire Rods}

The $115 \mathrm{~mm}$ squ. continuously cast billet which was obtained by the electric arc furnace was rolled to a section of $85 \mathrm{~mm}$ squ., and reduced to a size of $6 \mathrm{~mm}$ dia.

The chemical composition of the stainless steel is shown in Table 1. Photo. 2 illustrates macrostructure of transversal sections of a continuously cast billet, an $85 \mathrm{~mm}$ squ. billet, and $6 \mathrm{~mm}$ dia. wire rods. In the continuously cast billet and $85 \mathrm{~mm}$ squ. billet, columnar crystals develop uniformly from the surface up to a centre, forming a central shrinkage pipe. Such shrinkage is not found in the $6 \mathrm{~mm}$ dia. wire rods, but some segregation was observed in the form of an eye in each of the $6 \mathrm{~mm}$ dia. wire rods. The continuously cast billet and an $85 \mathrm{~mm}$ squ. billet showed

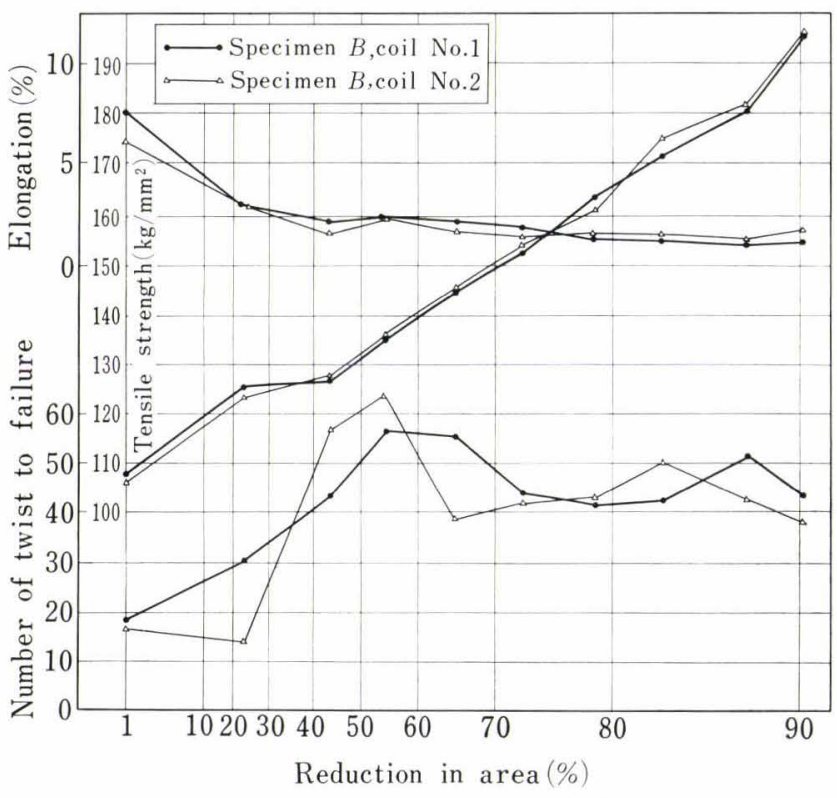

Fig. 3. Mechanical properties and twistability of hard steel wire during cold drawing

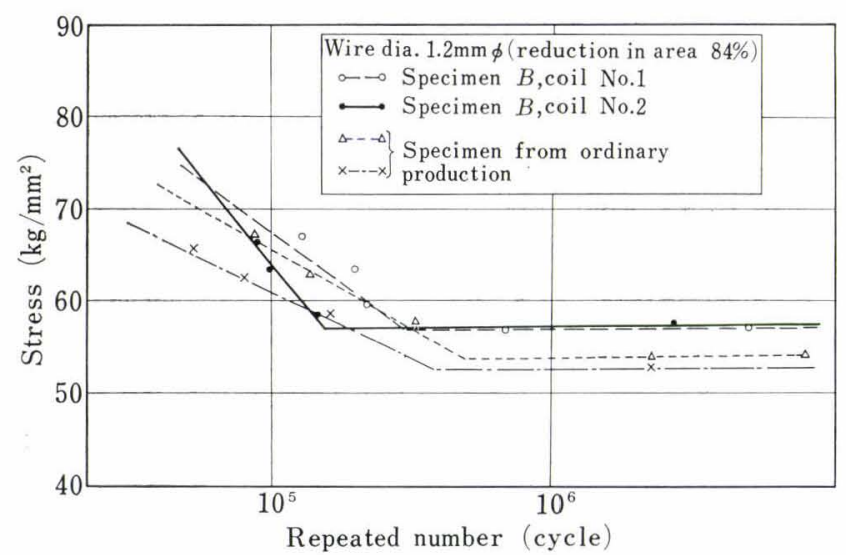

Fig. 4. Stress-repeated number curve of hard steel wire

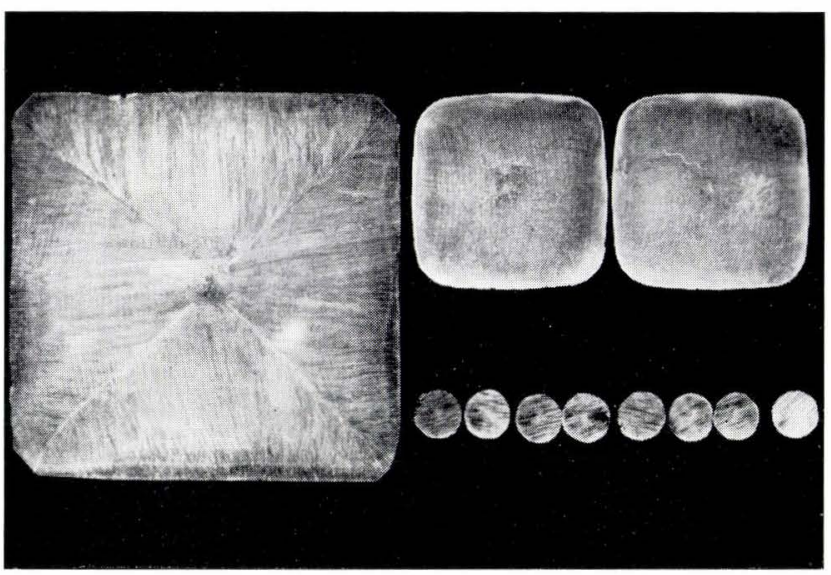

Photo. 2. Macrostructure of 18-8 stainless steel cast billet, $85 \mathrm{~mm}$ squ. and $6 \mathrm{~mm}$ round

no dissimilarity to the product obtained from the conventional ingot on the test of macro-streak flow and nonmetallic inclusions. The $6 \mathrm{~mm}$ dia. wire rods were further drawn to smaller diameter of 4 , 1.25 , and $1.10 \mathrm{~mm}$. Test specimens were picked up in the different stages of drawing, and were subjected to mechanical tests. Table 2 shows the mechanical properties and twistabilities of the specimens in the course of drawing.

The drawability and mechanical properties of above mentioned wire rods were not different from those of the product obtained from the conventional ingots.

\section{Spring Steel ${ }^{12)}$}

$115 \mathrm{~mm}$ squ. continuously cast billets obtained by the electric arc furnace were rolled to the crosssectional areas of $60 \times 6,100 \times 10,125 \times 13,80 \times 10$, and $100 \times 16(\mathrm{~mm})$ after entire surface grinding. The chemical compositions of the spring steel are shown in Table 3.

Photo. 3 shows macrostructures of continuously cast billets and the hot rolled products. In the hotrolled products the central shrinkage pipes which are found in the continuously cast billet are completely pressed to naught, but linear segregation is noted in the central portions. When the microstructures of the segregation zone are compared with those of the sound zone, the crystalline grains are somewhat finer in the segregation zone, but otherwise there is no structural difference.

The products rolled from the continuously cast billets are commonly believed to have less distinctly developed fiber grain flow structure because of the relatively small reduction ratio as compared with the products obtained from the conventional ingots. Accordingly, the rolled products were subjected to Charpy test for comparison with the products obtained from the conventional ingots. The portions sampled are shown in Fig. 5 and the test results are given in Table 4 . The results of determination of the directionality by Charpy test proved that there is no distinction between the both products. No dissimilarity is noted in mechanical properties and hardenability too. 
Table 2. Mechanical properties and twistability of 18-8 stainless steel

\begin{tabular}{|c|c|c|c|c|c|}
\hline \multirow[b]{2}{*}{ Size } & \multicolumn{3}{|c|}{ Mechanical properties } & \multirow{2}{*}{$\begin{array}{c}\text { Number } \\
\text { of } \\
\text { twist to } \\
\text { failure } \\
1=100 \mathrm{~d}\end{array}$} & \multirow{2}{*}{$\begin{array}{l}\text { Ben } \\
\text { test } \\
\text { times } \\
R=5\end{array}$} \\
\hline & $\begin{array}{c}\text { Tensile } \\
\text { st. } \\
\left(\mathrm{kg} / \mathrm{mm}^{2}\right)\end{array}$ & $\begin{array}{c}\text { Elonga- } \\
\text { tion } \\
(\%)\end{array}$ & $\begin{array}{l}\text { Reduc- } \\
\text { tion of } \\
\text { area }(\%)\end{array}$ & & \\
\hline 6.13 & 71.5 & 47.0 & 70.0 & - & - \\
\hline 4.52 & 132.0 & 2.0 & 53.0 & 1 & 4 \\
\hline $4.47 W T$ & 71.5 & 41.0 & 68.7 & 75 & \\
\hline 4.00 & 99.0 & 14.0 & 61.0 & 30 & 8 \\
\hline $4.00 \mathrm{~A}$ & 66.8 & 50.0 & 75.0 & 66 & - \\
\hline 6.16 & 71.2 & 44.0 & 69.5 & - & - \\
\hline 4.70 & 123.2 & 3.0 & 52.0 & - & - \\
\hline 3.82 & 143.8 & 3.0 & 46.5 & - & - \\
\hline 3.40 & 155.5 & 1.5 & 37.0 & 1 & 4 \\
\hline $3.40 W T$ & - & - & - & - & - \\
\hline 2.70 & 123.0 & 2.5 & 56.0 & 3 & 8 \\
\hline 2.19 & 152.0 & 2.0 & 48.0 & 3 & 8 \\
\hline 1.79 & 176.5 & 1.5 & 38.7 & 3 & 11 \\
\hline $1.77 W \mathrm{WT}$ & 71.6 & 4.2 & 68.7 & 74 & 17 \\
\hline 1.45 & 133.5 & 2.0 & 47.6 & 3 & 13 \\
\hline 1.35 & 144.0 & 1.5 & 45.0 & 3 & 11 \\
\hline $1.35 A$ & 72.0 & 44.0 & 69.2 & 66 & 21 \\
\hline 1.10 & 123.0 & 3.0 & 58.8 & 5 & 16 \\
\hline $1.085 \mathrm{~A}$ & 72.8 & 41.0 & 69.5 & 67 & 31 \\
\hline 6.12 & 71.7 & 45.0 & 69.0 & & - \\
\hline 4.70 & 124.0 & 3.0 & 52.1 & & - \\
\hline 3.81 & 146.5 & 3.0 & 46.0 & - & - \\
\hline 3.40 & 160.5 & 2.0 & 46.0 & 4 & 1 \\
\hline $3.41 W T$ & 69.5 & 43.0 & 68.0 & 70 & - \\
\hline 2.70 & 124.0 & 2.0 & 55.6 & 2 & 8 \\
\hline 2.19 & 151.5 & 2.0 & 47.1 & 3 & 8 \\
\hline 1.88 & 170.5 & 2.0 & 40.0 & 3 & 10 \\
\hline $1.87 W T$ & 69.2 & 44.0 & 65.0 & 70 & 17 \\
\hline 1.45 & 123.5 & 3.0 & 57.5 & 2 & 13 \\
\hline 1.35 & 146.0 & 2.0 & 45.3 & 3 & 11 \\
\hline $1.35 \mathrm{~A}$ & 73.0 & 42.0 & 69.2 & 68 & 23 \\
\hline 1.26 & 90.6 & 23.0 & 64.6 & 40 & 21 \\
\hline
\end{tabular}

$W T$ : water tough

$A$ : annealing

Table 3. Chemical analyses of spring steel (\%)

\begin{tabular}{c|ccccccc}
\hline Specimen & $\mathrm{C}$ & $\mathrm{Si}$ & $\mathrm{Mn}$ & $\mathrm{P}$ & $\mathrm{S}$ & $\mathrm{Cr}$ & $\mathrm{Ni}$ \\
\hline$A$ & 0.85 & 0.32 & 0.40 & 0.022 & 0.010 & 0.14 & 0.09 \\
$B$ & 0.58 & 0.32 & 0.84 & 0.026 & 0.009 & 0.83 & 0.06 \\
$C$ & 0.56 & 0.31 & 0.69 & 0.024 & 0.023 & 0.72 & 0.08 \\
$D$ & 0.56 & 0.31 & 0.74 & 0.029 & 0.010 & 0.74 & 0.08
\end{tabular}

Specimens $A$ and $B$ : continuously cast billet

Specimens $C$ and $D$ : conventionally cast ingot

\section{High-Carbon Steel Hoop ${ }^{13)}$}

$115 \mathrm{~mm}^{2}$ continuously cast billets obtained by the electric arc furnace were hot-rolled to a $3 \mathrm{~mm}$ thick steel hoop, and further cold-rolled to a thickness of $0.37 \mathrm{~mm}$. In different stages of the operations the products were sampled and compared with the corres-

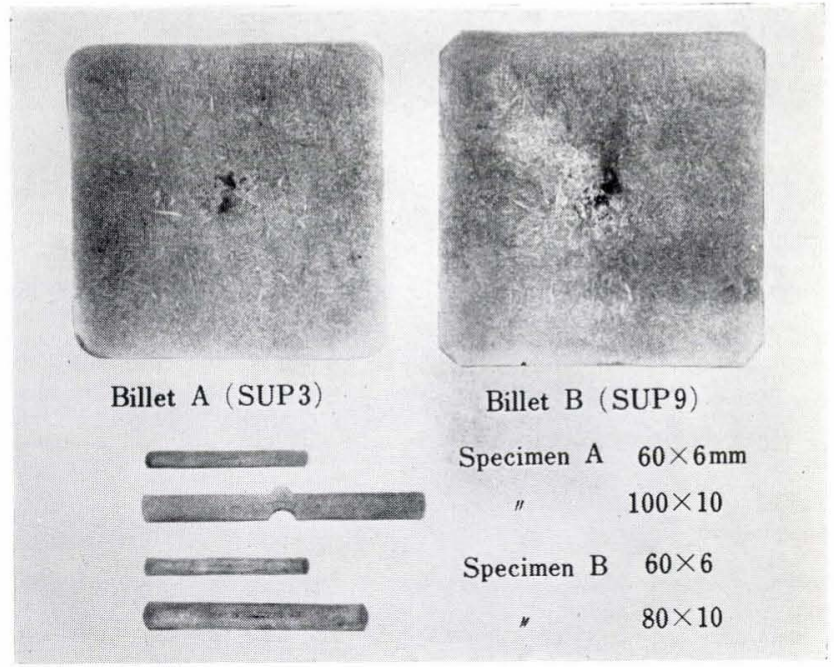

Photo. 3. Macrostructure of cast billet and hot rolled steel

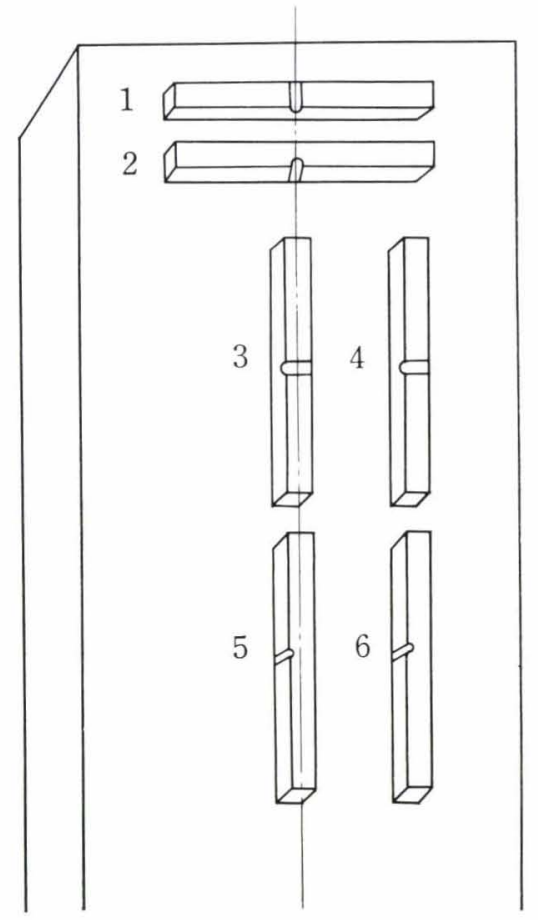

Fig. 5. Charpy test specimen from rolled steel $B, C$, and $D$. From each specimen were sampled 6 pieces (4 pieces from each).

$$
\begin{array}{ll}
\text { Specimen : } & B, C, \text { and } D \\
\text { Notch: } & 1.5 \mathrm{~mm} U \text {-notch } \\
\text { Treatment: } & 845^{\circ} \mathrm{C} \text { oil quench } \\
& 85^{\circ} \mathrm{C} \text { air cool }
\end{array}
$$

ponding products obtained from the conventional ingots. The chemical composition of the high-carbon steel hoop is shown in Table 5 .

Photo. 4 shows macrostructures of transversal sections of continuously cast billets and a $3 \mathrm{~mm}$ thick steel hoop. As shown in Photo. 4, a linear segregation is observed across the transversal section of the hoop. In microstructure the crystalline grains in the segregation zone are somewhat finer than those in the sound zone. 
Table 4. Results of Charpy test for specimens $B, C$, and $D$

\begin{tabular}{|c|c|c|c|c|c|c|c|c|}
\hline Specimen & $\begin{array}{l}\text { Hardness } \\
\qquad\left(\mathrm{H}_{\mathrm{R}} \mathrm{C}\right)\end{array}$ & $\begin{array}{c}\text { Charpy } \\
\text { impact value } \\
(\mathrm{kg} \cdot \mathrm{m} / \mathrm{cm})\end{array}$ & Specimen & $\begin{array}{c}\text { Hardness } \\
\qquad\left(\mathrm{H}_{\mathrm{R}} \mathrm{C}\right)\end{array}$ & $\begin{array}{c}\text { Charpy } \\
\text { impact value } \\
(\mathrm{kg} \cdot \mathrm{m} / \mathrm{cm})\end{array}$ & Specimen & $\begin{array}{l}\text { Hardness } \\
\left(\mathrm{H}_{\mathrm{R}} \mathrm{C}\right)\end{array}$ & $\begin{array}{c}\text { Charpy } \\
\text { impact value } \\
(\mathrm{kg} \cdot \mathrm{m} / \mathrm{cm})\end{array}$ \\
\hline$B 1-1$ & 44 & 2.7 & $C 1-1$ & 42 & 1.9 & $D 1-1$ & 43 & 1.9 \\
\hline 2 & 43 & 2.7 & 2 & 43 & 1.9 & 2 & 44 & 2.4 \\
\hline 3 & 44 & 2.4 & 3 & 43 & 1.9 & 3 & 43 & 2.2 \\
\hline 4 & 45 & 2.7 & 4 & 43 & 1.9 & 4 & 44 & 2.4 \\
\hline$B 2-1$ & 44 & 2.7 & $C 2-1$ & 42 & 2.4 & D2-1 & 44 & 2.7 \\
\hline 2 & 43 & 2.7 & 2 & 43 & 3.1 & 2 & 44 & 1.9 \\
\hline 3 & 43 & 3.1 & 3 & 43 & 3.1 & 3 & 44 & 2.2 \\
\hline 4 & 43 & 3.1 & 4 & 43 & 2.7 & 4 & 44 & 2.2 \\
\hline$B 3-1$ & 45 & 3.1 & C3-1 & 43 & 3.6 & D3-1 & 43 & 3.1 \\
\hline 2 & 44 & 3.4 & 2 & 43 & 3.9 & 2 & 44 & 3.1 \\
\hline 3 & 43 & 3.1 & 3 & 43 & 3.6 & 3 & 44 & 3.2 \\
\hline 4 & 43 & 3.1 & 4 & 44 & 3.4 & 4 & 43 & 3.4 \\
\hline$B 4-1$ & 45 & 2.7 & C4-1 & 43 & 3.4 & $D 4-1$ & 43 & 3.1 \\
\hline 2 & 43 & 3.6 & 2 & 44 & 3.6 & 2 & 43 & 3.1 \\
\hline 3 & 45 & 2.7 & 3 & 44 & 3.4 & 3 & 43 & 3.1 \\
\hline 4 & 44 & 3.1 & 4 & 43 & 3.6 & 4 & 44 & 3.1 \\
\hline B5-1 & 43 & 2.7 & C5-1 & 44 & 3.6 & D5-1 & 44 & 2.7 \\
\hline 2 & 43 & 3.4 & 2 & 44 & 3.6 & 2 & 44 & 3.1 \\
\hline 3 & 44 & 3.9 & 3 & 44 & 3.6 & 3 & 44 & 3.1 \\
\hline 4 & 43 & 3.6 & 4 & 44 & 3.6 & 4 & 44 & 2.7 \\
\hline$B 6-1$ & 43 & 4.8 & C6-1 & 44 & 3.9 & $D 6-1$ & 43 & 2.7 \\
\hline 2 & 44 & 3.4 & 2 & 43 & 3.9 & 2 & 44 & 3.4 \\
\hline 3 & 43 & 3.4 & 3 & 43 & 3.6 & 3 & 45 & 3.1 \\
\hline 4 & 43 & 3.4 & 4 & 43 & 3.9 & 4 & 44 & 3.1 \\
\hline
\end{tabular}

Table 5. Chemical analysis of high-carbon steel hoop (\%)

\begin{tabular}{ccccc} 
C & Si & Mn & P & S \\
\hline 0.82 & 0.30 & 0.40 & 0.014 & 0.012 \\
\hline
\end{tabular}

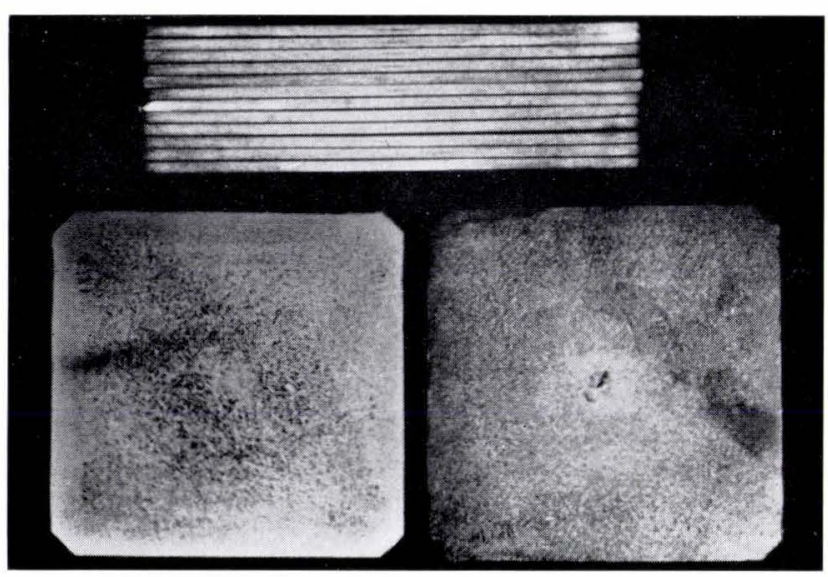

Photo. 4. Macrostructure and sulphur print (right) of cast billet and hot-rolled steel hoop

Table 6 indicates the results of tensile tests conducted for the specimens taken from each sampling position and direction of $3 \mathrm{~mm}$ thick steel hoop, as compared with the results of similar tests with the products obtained from the conventional ingots. As shown in the table, there is little difference between the both products.

$5 \mathrm{~mm}$ thick samples were prepared by shaving off equal depth from both sides of $8 \mathrm{~mm}$ thick as-rolled blanks representing different locations of the entire coil, and were subjected to Schenck fatigue test by applying repeated bending stress. For the comparison, test specimens prepared from the products obtained from the conventional ingots were also tested. The results are shown in Fig. 6. (See p. 294.) It is obvious from the figure that the fatigue property of the steel hoop made from the continuously cast billet is comparable to or superior to that of the ordinary products obtained from the conventional ingot. No difference was recognized in the values resulted from different sampling positions and directions.

In case of $0.37 \mathrm{~mm}$ thick steel hoop (cold finished hoop) obtained by cold-rolling $3 \mathrm{~mm}$ thick hotrolled hoop, the surface condition was satisfactory with no undesirable defect and there was no considerable dissimilarity to the conventional products in the yield.

From different position of the hoop, test specimens were taken and tested. The results are shown in Table 7.

No irregularity was observed among the values of specimens taken from different positions. Also, the values were comparable to those of the conventional 
Table 6. Mechanical properties of hot coil $\left(820^{\circ} \mathrm{C} 30 \mathrm{~min}\right.$ annealing)

\begin{tabular}{|c|c|c|c|c|c|c|}
\hline \multicolumn{2}{|c|}{ Specimen } & $\begin{array}{l}\text { Position } \\
\text { of } \\
\text { specimen (kg }\end{array}$ & $\begin{array}{l}\text { Yield } \\
\mathrm{pt.} \\
\mathrm{g} / \mathrm{mr}\end{array}$ & $\begin{array}{l}\text { Tensile } \\
\text { st. } \\
\left(\mathrm{kg} / \mathrm{mm}^{2}\right)\end{array}$ & $\begin{array}{l}\text { Elonga- } \\
\text { tion } \\
(\%)\end{array}$ & $\begin{array}{c}\text { Hard- } \\
\text { ness } \\
\mathrm{H}_{\mathrm{R}} \mathrm{B}\end{array}$ \\
\hline \multirow{12}{*}{ 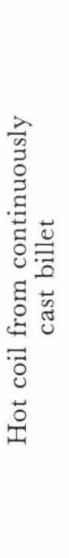 } & \multirow{3}{*}{$A$} & $E$ & 60 & 97 & 18.6 & 104.5 \\
\hline & & $C$ & 61 & 98 & 17.7 & 104.5 \\
\hline & & $\mathcal{T}$ & 60 & 100 & 18.2 & 103.9 \\
\hline & \multirow{3}{*}{$B$} & $E$ & 59 & 97 & 16.4 & 103.9 \\
\hline & & $C$ & 59 & 99 & 16.6 & 104.1 \\
\hline & & $T$ & 60 & 98 & 15.9 & 104.8 \\
\hline & \multirow{3}{*}{$C$} & $E$ & 61 & 98 & 8.0 & 103.2 \\
\hline & & $C$ & 60 & 100 & 17.7 & 102.9 \\
\hline & & $T$ & 63 & 100 & 17.9 & 102.3 \\
\hline & \multirow{3}{*}{$D$} & $E$ & 61 & 98 & 17.8 & 103.6 \\
\hline & & $C$ & 59 & 98 & 17.8 & 102.2 \\
\hline & & $T$ & 62 & 99 & 16.9 & 103.4 \\
\hline \multirow{12}{*}{ 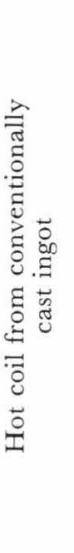 } & \multirow{3}{*}{1} & $E$ & 58 & 99 & 18.2 & 105.1 \\
\hline & & $C$ & 59 & 100 & 17.9 & 105.1 \\
\hline & & $T$ & 48 & 101 & 16.0 & 103.9 \\
\hline & \multirow{3}{*}{2} & $E$ & 58 & 99 & 17.9 & 104.9 \\
\hline & & $C$ & 58 & 99 & 17.7 & 102.3 \\
\hline & & $T$ & 58 & 100 & 16.8 & 104.1 \\
\hline & \multirow{3}{*}{3} & $E$ & 58 & 100 & 15.5 & 106.1 \\
\hline & & $C$ & 58 & 101 & 16.1 & 105.5 \\
\hline & & $\mathcal{T}$ & 60 & 101 & 17.7 & 105.7 \\
\hline & \multirow{3}{*}{4} & $E$ & 60 & 101 & 17.7 & 105.7 \\
\hline & & $C$ & 59 & 101 & 17.0 & 104.6 \\
\hline & & $T$ & 58 & 99 & 17.9 & 105.0 \\
\hline
\end{tabular}

Position of specimens

$E$ : longitudinal direction and edge part

$C$ : longitudinal direction and centre part

$T$ : transversal direction

Table 7. Mechanical properties of cold-rolled steel hoop

\begin{tabular}{r|cccc}
\hline $\begin{array}{c}\text { Position of } \\
\text { specimen }\end{array}$ & $\begin{array}{c}\text { Hardness } \\
(\mathrm{Hv})\end{array}$ & $\begin{array}{c}\text { Tensile st. } \\
\left(\mathrm{kg} / \mathrm{mm}^{2}\right)\end{array}$ & $\begin{array}{c}\text { Elonga- } \\
\text { tion }(\%)\end{array}$ & $\begin{array}{c}\text { Erichsen } \\
\text { test }(\mathrm{mm})\end{array}$ \\
\hline Trans. dir. centre p. & 163 & 55.8 & 32.3 & 8.3 \\
" edge p. & 164 & 56.1 & 31.9 & - \\
Longit. dir. outer p. & 163 & 56.1 & 31.6 & 8.3 \\
,$\quad$ inner p. & 164 & 55.8 & 32.7 & 8.3 \\
\hline
\end{tabular}

products.

For the properties of final products in the form of coiled springs, 16 pieces, each $0.37 \mathrm{~mm}$ thick and $8.00 \mathrm{~mm}$ wide, were cut off widthwise from the cold finished hoop having a thickness of $0.37 \mathrm{~mm}$ and a width of $136 \mathrm{~mm}$. A considerable number of test specimens were sampled in the direction of width. The results are given in Table 8 together with the values of the products obtained from the conventional ingots. From the table it is clear that all values are nearly equal to the values of standard material and it is obvious that there is no marked discrepancies in the properties of specimens obtained from the different positions.

As indicated above, the investigations on the applicability of continuously cast billets to the manufacture of steel hoops have proved that the products are not distinguishable from those products obtained from the conventional ingots.

\section{Forging Materials ${ }^{14)}$}

If continuously cast billets can be directly used as forging materials, an economical interest would be significant. As an approach to this possibility, continuously cast billets of carbon steel, 115 and 165 $\mathrm{mm}$ squ. billets made from the heat in the LD converter were forged into die forging and ring forging. The relation between the forging ratios and materials was studied, and the results were compared with those of the products obtained from the conventional ingots. The chemical compositions of the carbon steel are shown in Table 9.

The test specimens $A$ and $B$ were, after entire surface grinding, roughly forged, and then die forged. In this case, the forging ratio* was $4 S$ for the specimen $A$ and $8 S$ for the specimen $B$. The specimen $C$ was, after entire surface grinding, upset, punched, and forged for hole extention to a ring shape. The forging ratio was $1 / 1.2 \mathrm{U}$ and $2.5 \mathrm{E}$. Photo. 5 shows the macrostructure of die forgings. The macrostructures of transversal and longitudinal sections of rough forgings indicate that columnar crystals almost disappear in the forgings from the $165 \mathrm{~mm}$ squ. billet whereas columnar crystals are left in the considerable amount in the forgings from the $115 \mathrm{~mm}$ squ. billet.

Upon comparison of the macrostructures of die forgings, the products obtained from the conventional ingots exhibit distinct fibrous structures while the similar structures are scarcely observed in the forgings from the $165 \mathrm{~mm}$ squ. billet. In the forgings from the $115 \mathrm{~mm}$ squ. billet, however, columnar crystals still remain and central segregations are observed.

Observations of the macrostructures suggest that a forging ratio of over $8 S$ is considered to be necessary for the die forgings.

The ring forgings were made from the $165 \mathrm{~mm}$ squ. billet by upsetting, punching, and extend hollow forging to rings having an outside diameter of $260 \mathrm{~mm}$, inside diameter of $206 \mathrm{~mm}$ and a length of $196 \mathrm{~mm}$.

The ringed products are completely free from the columnar crystals observed in the continuously cast billet, and because the central segregation has been eliminated by punching, they have a homogeneous structure and a normal microstructure. As regards

\footnotetext{
* Forming ratio for steel forging

Forming ratio of rough forging (symbol $S$ ) indicates the ratio of sectional area before and after forging.

Forming ratio of upset forging (symbol $U$ ) indicates the ratio of length before and after forging.

Forming ratio of hole extention forging (symbol $E$ ) indicates the ratio of difference between outer diameter and inner diameter, before and after forging.
} 


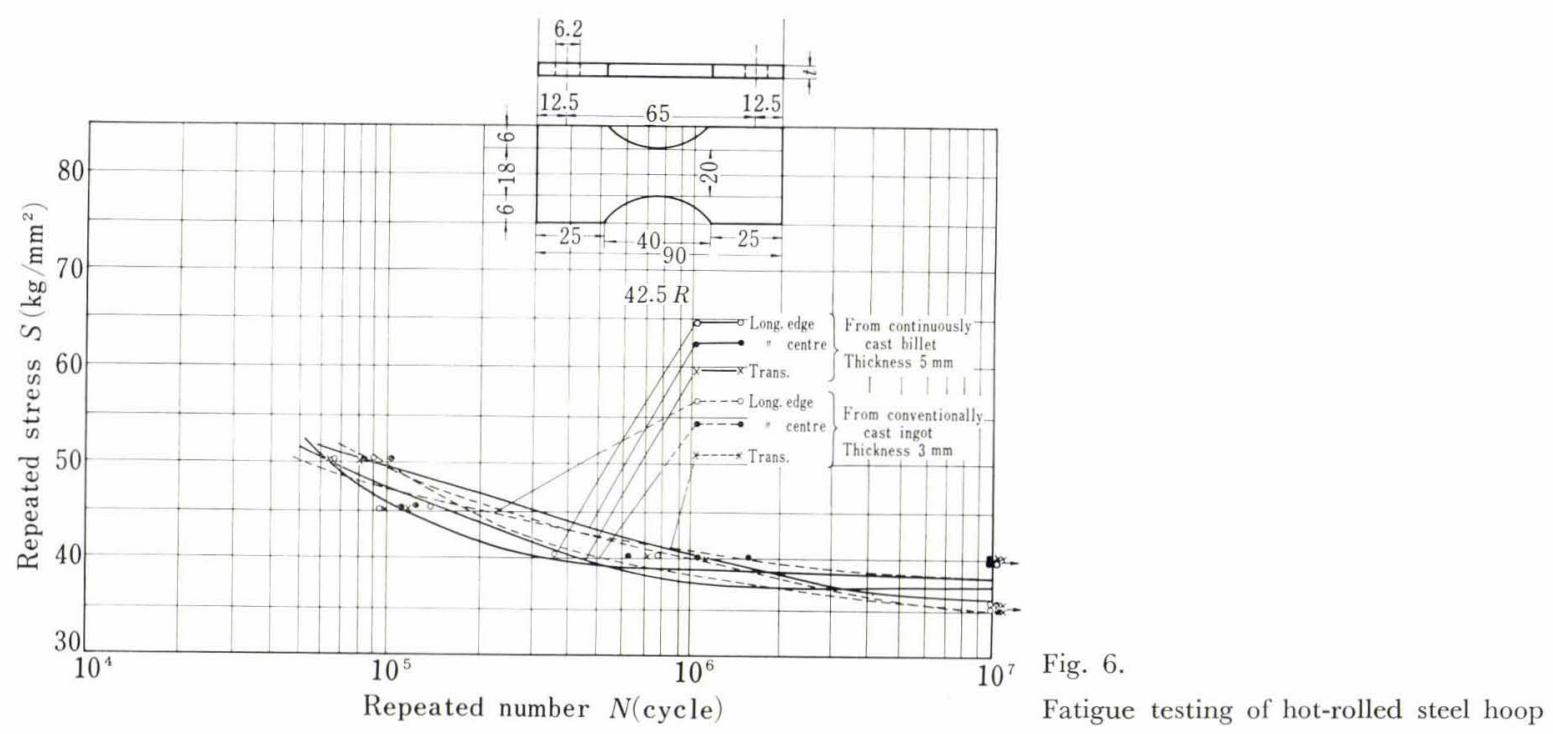

Table 8. Mechanical properties of high-carbon steel springs

\begin{tabular}{|c|c|c|c|c|c|c|c|c|c|}
\hline Specimen & $\begin{array}{l}\text { Position } \\
\text { of } \\
\text { specimen }\end{array}$ & $\begin{array}{l}\text { Number } \\
\text { of } \\
\text { specimen }\end{array}$ & Standard & $\begin{array}{c}\text { Thickness } \\
0.37 \pm 0.012\end{array}$ & $\begin{array}{c}\text { Width } \\
8.0 \pm 0.1\end{array}$ & $\begin{array}{l}\text { Hardness } \\
\text { Hs } 67-73\end{array}$ & $\begin{array}{c}\mathrm{T}^{\text {Tor }} \\
(n=8) \\
\leq 4.2\end{array}$ & $\begin{array}{l}\text { que } \\
\qquad \begin{array}{l}(n=8) \\
\geq 1.2\end{array}\end{array}$ & $\begin{array}{c}\text { Fatigue } \\
\text { min. } \geq 4000 \\
\text { mean } \geq 12000\end{array}$ \\
\hline \multirow{6}{*}{$\begin{array}{l}\text { Cold-rolled steel hoop } \\
\text { from continuously cast } \\
\text { billet }\end{array}$} & \multirow{2}{*}{$E$} & \multirow{2}{*}{12} & $\int \bar{x}$ & 0.360 & 8.00 & 68.6 & 3.12 & 1.58 & \multirow{6}{*}{$\begin{array}{l}\text { All } \\
\geq 12000\end{array}$} \\
\hline & & & $\mathrm{R}$ & 0.027 & 0.03 & 1.5 & 1.3 & 0.3 & \\
\hline & \multirow[b]{2}{*}{$C$} & \multirow{2}{*}{14} & $\bar{x}$ & 0.375 & 8.03 & 68.8 & 3.05 & 1.61 & \\
\hline & & & $\mathrm{R}$ & 0.013 & 0.05 & 2.0 & 1.0 & 0.5 & \\
\hline & \multirow{2}{*}{$M$} & \multirow{2}{*}{12} & $\overline{\mathrm{X}}$ & 0.374 & 8.00 & 69.1 & 3.20 & 1.61 & \\
\hline & & & $\mathrm{R}$ & 0.012 & 0.10 & 1.5 & 1.15 & 0.25 & \\
\hline \multirow{2}{*}{$\begin{array}{l}\text { From conventionally } \\
\text { cast ingot }\end{array}$} & \multirow{2}{*}{$\begin{array}{l}C \\
\text { or } \\
M\end{array}$} & \multirow{2}{*}{50} & $\int \bar{x}$ & 0.377 & 7.9 & 69.3 & 3.35 & 1.51 & \multirow[b]{2}{*}{$"$} \\
\hline & & & $\mathrm{R}$ & 0.025 & 0.12 & 3.0 & 1.8 & 0.54 & \\
\hline
\end{tabular}

Position of specimen : $E$ edge, $C$ centre, $M$ middle

Table 9. Chemical analyses of carbon steel for forgings (\%)

\begin{tabular}{cc|ccccccc}
\hline Specimen & $\begin{array}{c}\text { Billet } \\
\text { size } \\
\text { (mm squ.) }\end{array}$ & C & Si & Mn & P & S & Cu \\
\hline$A$ & 115 & 0.48 & 0.25 & 0.64 & 0.020 & 0.017 & 0.01 \\
$B$ & 165 & 0.44 & 0.27 & 0.62 & 0.025 & 0.022 & 0.01 \\
$C$ & 165 & 0.09 & 0.23 & 0.31 & 0.021 & 0.014 & 0.03 \\
\hline
\end{tabular}

their mechanical properties, the die forgings and ring forgings having ratios of both $4 S$ and $8 S$ showed satisfactory values.

In the case of die forgings having forging ratios of over $3 S$ and ring forgings having forging ratios of $1 / 1.2 U$ and $2.5 \mathrm{E}$, it has been found that products were well comparable to those of the products obtained from the conventional ingots.

\section{Conclusions}

The plant operation conducted in the Hachinohe works was reviewed and the qualities of products rolled and forged of continuously cast billets were studied.

The results have led to the following conclusions.

(1) Hard steel wire rods and stainless steel wire rods made from continuously cast billets have approxi- mately the same drawability, fatigue resistance, and other mechanical properties with those of the products obtained from the conventional ingots.

In case of the hard steel wire rods, it has become clear that the step of surface treatment can be omitted.

(2) Spring steel products rolled from the continuously cast billets exhibit linear segregation marks in the central portions of macrostructures. However, microscopic observation and the results of Charpy test suggest that such segregation is not regarded as defects. Further, the results of Charpy test on the directionality of the spring steel products showed no discernible difference from those of the products obtained from the conventional ingots.

(3) Hot-rolled steel hoops of high-carbon steel made from continuously cast billets showed linear segregation marks in the macrostructures which were similar to the marks in the spring steel products. Still, according to test results, the former was well comparable to the products obtained from the conventional ingots in mechanical properties and fatigue resistance.

(4) The qualities of the cold steel hoops and the spring as final products that were made from the continuously cast billets were such that the mechanical properties, and deep drawability of the cold finished 


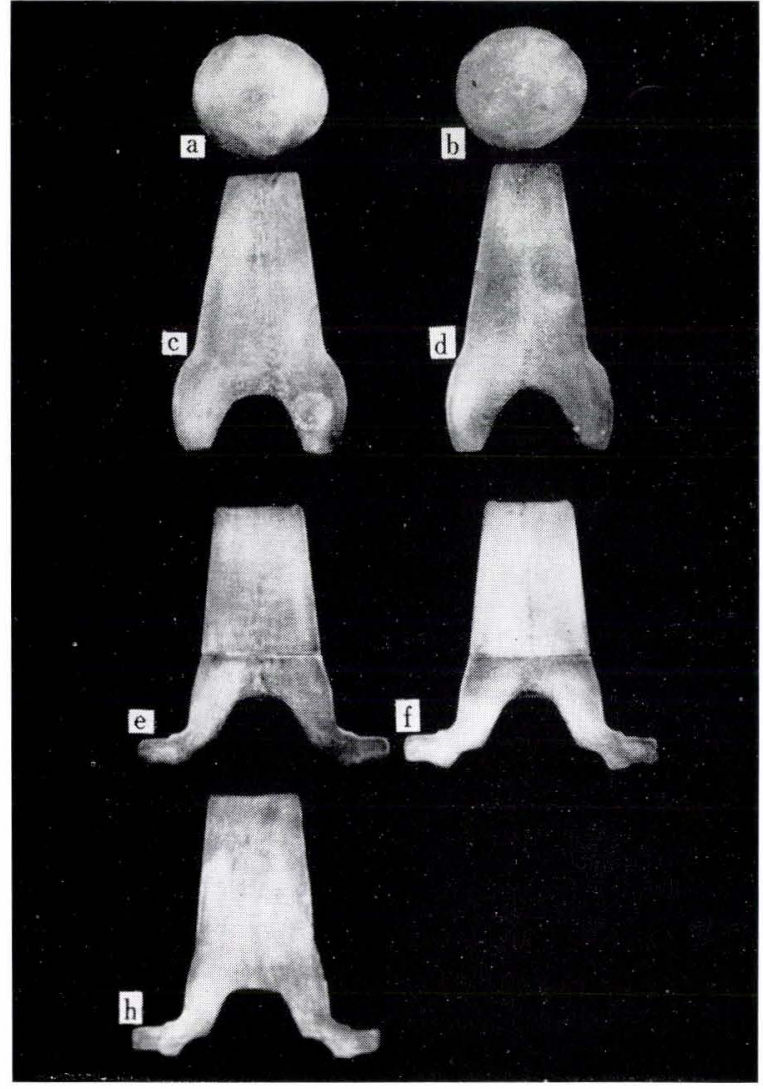

Photo. 5. Macrostructure of die forgings

$\left.\begin{array}{rll}\text { a, c: } & \text { rough forg. from } 165 \mathrm{~mm} & \begin{array}{l}\text { billet trans. and } \\ \text { longitud. }\end{array} \\ \text { b, d: } & \text { rough forg. from } 115 \mathrm{~mm} \\ \text { e: } & \text { die forg. from a, c } \\ \text { f: } & \text { die forg. from b, d } \\ \text { h: } & \text { die forg. from material } \\ & \text { of conventional cast } \\ & \text { ingot }\end{array}\right\}$ longitud. section

hoops, and hardness, fatigue resistance, and other properties of the coiled springs were satisfactory so far as the values actually determined are concerned.

(5) The experiment on die forgings and ring forgings made from the continuously cast billets showed that die forgings having forging ratios of over $8 S$ and ring forgings having forging ratios of $1 / 1.2 \mathrm{U}$ and $2.5 \mathrm{E}$ had the same qualities with the similar products obtained from the conventional ingots. The mechanical properties of die forgings having forging ratios of over $4 S$ were well comparable to the products obtained from the conventional ingots, as indicated in the literatures. ${ }^{6)-10)}$
Table 10. Steel quality for continuous casting under production

\begin{tabular}{l|ccc}
\multicolumn{1}{c|}{ Steel quality } & $\begin{array}{c}115 \\
\text { mm squ. }\end{array}$ & $\begin{array}{c}165 \\
\text { mm squ. }\end{array}$ & $\begin{array}{c}750 \\
\times 150 \mathrm{~mm}\end{array}$ \\
\hline $\begin{array}{l}\text { Low-carbon steel for mild } \\
\text { steel wire rods and rolled } \\
\text { steel for general purpose }\end{array}$ & 0 & 0 \\
\hline $\begin{array}{l}\text { High-carbon steel for hard } \\
\text { steel wire rods and music } \\
\text { wire rods }\end{array}$ & 0 & 0 \\
\hline $\begin{array}{l}\text { Tool steel for cold-rolled } \\
\text { steel hoop }\end{array}$ & 0 & 0 \\
\hline $\begin{array}{l}\text { Low- and high-carbon steel } \\
\text { for forgings }\end{array}$ & 0 & 0 \\
\hline $\begin{array}{l}\text { 18-8 stainless steel for wire } \\
\text { and sheet }\end{array}$ & 0 & $\bigcirc$ \\
\hline Spring steel & 0 & \\
\hline
\end{tabular}

On the basis of the results of investigation herein above, the authors' steel plant produces currently various kinds of continuously cast billets as enumerated in Table 10 .

\section{Acknowledgements}

Grateful acknowledgement is made to Mannesmann A. G. and Gebr. Boehler A. G. for the technical assistance extended since the very beginning of the authors' continuous casting operation. Thanks are also due to Daido Steel Co., Ltd., Mitsubishi Steel Co., Ltd., and Japan Special Steel Co.g Ltd. for their co-operation in the investigations herein reported.

\section{REFERENCES}

1) S. Koike and T. Hikage: Tetsu-to-Hagané, 51 (1965), 224.

2) K. Ushijima: J. Iron Steel Inst., (U.K.) 203 (1965), 329.

3) B. Tarmann: Technische Mitteilungen, 54 (1961), 88.

4) M. M. Misson: Ingenieurs de L'Automobile, No. 6 (1962), 319.

5) G. Forstner-Billau and B. Tarmann: Berg- und Huettenmannische Monatshefte, 111 (1966), 252.

6) K. Saigo: Iron Steel Eng., 16 (1964), 71.

7) C. Wells : Continuous Casting, (1962), John Wiley \& Sons, New York.

8) D.J. Wulpi: Metal Progress, 86 (1964), Dec., 72.

9) D. I. Brown: J. Metals, 17 (1965), 426; 18 (1966), 69.

10) R. Rosegger: Berg- und Huettenmannische Monatshefte, 111 (1966), 243.

11) S. Koike and A. Kimura: Tetsu-to-Hagané, 52 (1966), 273.

12) S. Koike: Tetsu-to-Hagané, 52 (1966), 275.

13) M. Yamaguchi and S. Koike: Tetsu-to-Hagané, 52 (1966), 92.

14) S. Koike and A. Kimura: Tetsu-to-Hagané, 53 (1967), 72. 